\title{
METAL PARTICLES SIZE INFLUENCE ON GRADED STRUCTURE IN COMPOSITE $\mathrm{Al}_{2} \mathrm{O}_{3}-\mathrm{Ni}$
}

\author{
VPLIV VELIKOSTI KOVINSKIH DELCEV NA GRADIENTNO \\ STRUKTURO KOMPOZITA $\mathrm{Al}_{2} \mathrm{O}_{3}-\mathrm{Ni}$
}

\author{
Justyna Zygmuntowicz, Aleksandra Miazga, Katarzyna Konopka, \\ Waldemar Kaszuwara \\ University of Technology, Faculty of Materials Science and Engineering, Woloska St. 141, 02-507 Warsaw, Poland \\ justyna.zygmuntowicz@inmat.pw.edu.pl \\ Prejem rokopisa - received: 2015-06-15; sprejem za objavo - accepted for publication: 2015-07-28
}

doi: $10.17222 /$ mit. 2015.120

\begin{abstract}
The aim of this study was to investigate the effect of the nickel particle size on the changes in metallic phase content in the graded structure in the $\mathrm{Al}_{2} \mathrm{O}_{3}-\mathrm{Ni}$ composites. Centrifugal slip casting was chosen as the method of composite fabrication. This method allows the creation of a graded distribution of Ni particles in the hollow cylinder composite sample. Functional graded materials were prepared in the vertical rotation axis. In the experiments the following powders were used: $\alpha$-Al $\mathrm{O}_{3}$ TM-DAR from Taimei Chemicals (Japan) of an average particle size $0.133 \mu \mathrm{m}$ and density $3.96 \mathrm{~g} / \mathrm{cm}^{3}$ and $\mathrm{Ni}$ powders from Sigma-Aldrich of average particle sizes $3 \mu \mathrm{m}$ and $8.5 \mu \mathrm{m}$. Aqueous slurries containing alumina $(50 \%$ of volume fractions of solid phase volume content) and nickel powders (10\% of volume fractions) were tested. Deflocculates diammonium citrate (p.a., Aldrich) and citric acid (p.a., POCH Gliwice) were also added. Final sintering was conducted on all the specimens at $1400{ }^{\circ} \mathrm{C}$ in a reducing atmosphere $\left(\mathrm{N}_{2} / \mathrm{H}_{2}\right)$. The obtained samples were characterized by X-ray diffraction (XRD) and scanning electron microscopy (SEM). In addition, quantitative analyses of the Ni particles distribution were made. In the fabricated samples the graded structure were characterized by zones with different Ni particles concentration. The size of the Ni particles influences the width of these zones. Vickers indentation was used to determine the hardness of the materials.

Keywords: functionally graded material (FGM), centrifugal slip casting (CSC), $\mathrm{Al}_{2} \mathrm{O}_{3}$-Ni system

Namen študije je bil preiskati vpliv velikosti delcev niklja na spreminjanje vsebnosti kovinske faze v gradientni strukturi kompozita $\mathrm{Al}_{2} \mathrm{O}_{3}$-Ni. Centrifugalno oblikovalno ulivanje je bilo izbrano kot metoda za izdelavo kompozita. Ta metoda omogoča stopenjsko razporeditev delcev $\mathrm{Ni} v$ votlem cilindričnem kompozitnem vzorcu. Funkcionalno razporejen material je bil izdelan na vertikalni rotacijski osi. Za preizkuse so bili uporabljeni naslednji prahovi: $\alpha-\mathrm{Al}_{2} \mathrm{O}_{3}$ TM-DAR iz Taimei Chemicals (Japan) s povprečno velikostjo delcev $0.133 \mu \mathrm{m}$ in gostoto $3.96 \mathrm{~g} / \mathrm{cm}^{3}$ ter prah Ni iz Sigma-Aldrich, s povprečno velikostjo delcev $3 \mu \mathrm{m}$ in $8.5 \mu \mathrm{m}$. Preizkušena je bila na vodi osnovana mešanica ( $\mathrm{z}$ vsebnostjo $50 \%$ volumenskega deleža trdne faze), ki je vsebovala prah glinice in niklja (10\% volumenskega deleža). Uporabljeni deflokulant je bil sestavljen iz diamonium citrata (p.a., Aldrich) in citronske kisline (p.a., POCH Gliwice). Končno sintranje je bilo pri vseh vzorcih na $1400{ }^{\circ} \mathrm{C}$, v reduktivni atmosferi $\left(\mathrm{N}_{2} / \mathrm{H}_{2}\right)$. Dobljeni vzorci so bili pregledani z rentgensko difrakcijo (XRD) in vrstično elektronsko mikroskopijo (SEM). Poleg tega je bila izvedena tudi kvantitativna analiza razporeditve $\mathrm{Ni}$ delcev. V vzorcih je bila analizirana gradientna struktura po področjih $\mathrm{Z}$ različno koncentracijo Ni delcev. Velikost Ni delcev vpliva na širino teh področij. Določena je bila trdota materiala po Vickersu.

Ključne besede: funkcionalno gradientni material (FGM), centrifugalno oblikovalno ulivanje (CSC), $\mathrm{Al}_{2} \mathrm{O}_{3}-\mathrm{Ni}$ sistem
\end{abstract}

\section{INTRODUCTION}

Novel ceramic-metal composites should have a combination of properties such as good strength, high hardness together with high fracture toughness, wear and thermal resistance as well as chemical inertness, among others. Such demands may be fulfilled by functional graded materials (FGM). These materials are characterized by a variation in composition and structure gradually over volume, resulting in corresponding changes in the chemical and physical properties of the composite. ${ }^{1,2}$

The concept of graded materials was shown for the first time in 1971 in an article entitled "Preliminary work on Functionally Graded Materials". ${ }^{3}$ These materials can be prepared by a variety of methods. Currently, among the most popular techniques for producing FGM are powder technology methods, inter alia: dry powder compaction, ${ }^{3,4}$ tape casting, ${ }^{1,3,5-7}$ self-propagating high - tem- perature synthesis - SHS, ${ }^{7,8}$ slip casting and filtration. ${ }^{1,9-13}$ However, other in-situ techniques such as: spray forming, ${ }^{14,15}$ centrifugal casting ${ }^{1,16-19}$ and the deposition methods of Electrophoretic Deposition (EDP) ${ }^{20-26}$ and Pulsed Laser Deposition (PLD) ${ }^{27,28}$ have also gained broad attention.

Ceramic-metal composites with a gradient concentration of the metal particles are an example of FGM materials. Typical scheme of ceramic-metal FGM composites is shown in Figure 1. Such composites can be used as functional materials, and also as structural materials in the aerospace industry.

The principal advantage of ceramic matrix composites with metal particle concentration gradients is an increase of the fracture toughness with respect to the ceramic matrix..$^{29-31}$ The literature data indicate that the particle size and amount of the metal phase essentially affect crack propagation. ${ }^{32}$ Modification of the particle 


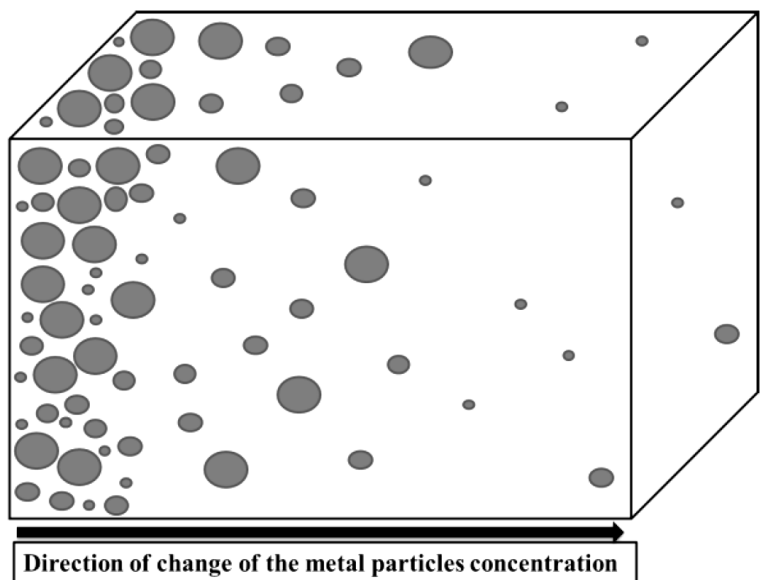

Figure 1: Schema of ceramic-metal FGM composite, dark-grey metal particles

Slika 1: Shema kompozita keramika-kovina FGM, temno sivo - delci kovine

size of metal in the composite enables precise control of the material properties.

In the present work, $\mathrm{Al}_{2} \mathrm{O}_{3}-\mathrm{Ni}$ composites with a concentration gradient of the metal particles were fabricated using centrifugal slip casting. This method allows fabrication of a graded distribution of Ni particles in a hollow cylinder composite sample. The aim of this study was to investigate the effect of the nickel particles size on the metallic phase content in graded $\mathrm{Al}_{2} \mathrm{O}_{3}-\mathrm{Ni}$ composites.

\section{EXPERIMENTAL PART}

\subsection{Materials and methods}

In the tests the following powders were used: $\alpha-\mathrm{Al}_{2} \mathrm{O}_{3}$ TM-DAR from Taimei Chemicals (Japan) of an average particle size $D_{50}=0.133 \mu \mathrm{m}$ and density 3.96 $\mathrm{g} / \mathrm{cm}^{3}$ and Ni powders from Sigma-Aldrich of average particle sizes $D_{50}=3 \mu \mathrm{m}$ and $D_{50}=8.5 \mu \mathrm{m}$. For both Ni particle sizes a series of composite samples were prepared. Aqueous slurries containing alumina (with 50 $\%$ of volume fractions content of solid phase) and nickel powder (10\% of volume fractions with respect to total volume) were tested. Deflocculates diammonium citrate (p.a., Aldrich) and citric acid (p.a., POCH Gliwice) were also added. Figure 2 shows the scanning electron microscopy images of $\alpha-\mathrm{Al}_{2} \mathrm{O}_{3}$ and the two Ni powders.

The components were homogenized in a planetary mill with a rotation speed of $300 \mathrm{~min}^{-1}$ for $90 \mathrm{~min}$. Afterwards, the air absorbed on the particle surfaces was removed in a THINKY ARE-250 Mixer and Degassing Machine for $15 \mathrm{~min}$ at a speed of $900 \mathrm{~min}^{-1}$. The equipment allows the removal of bubbles above $1 \mu \mathrm{m}$. The ceramic water-based slurries were cast into thick-walled tubes using a plaster mold. A stirrer with a vertical rotation axis was used in the centrifugal slip casting process. The process parameters were first chosen by set of trials. The dimensions of the fabricated tubes are as
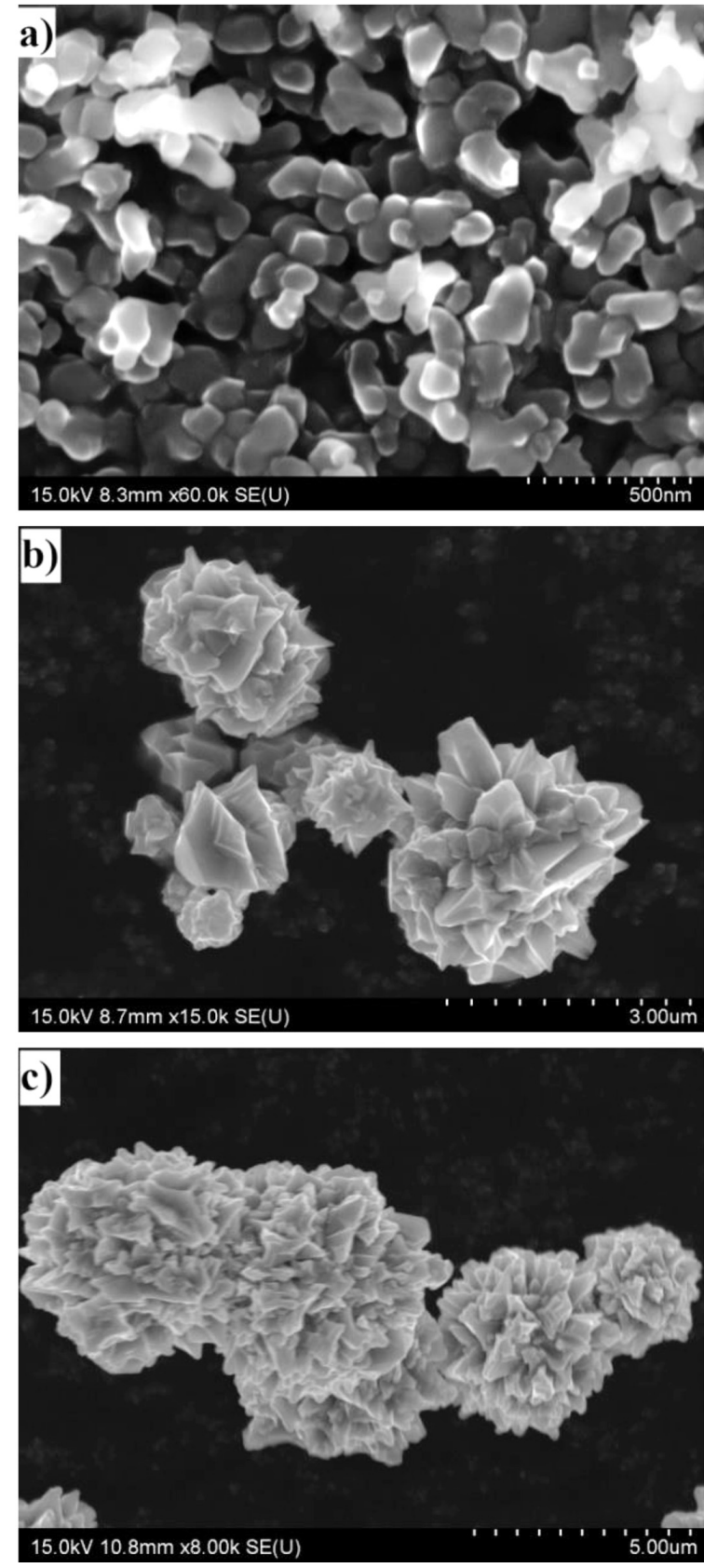

Figure 2: Electron micrographs of: a) $\alpha-\mathrm{Al}_{2} \mathrm{O}_{3}$, b) Ni powder, $\left(D_{50}=\right.$ $3 \mu \mathrm{m})$, c) Ni powder $\left(D_{50}=8.5 \mu \mathrm{m}\right)$

Slika 2: SEM posnetki: a) $\alpha-\mathrm{Al}_{2} \mathrm{O}_{3}$, b) prah $\mathrm{Ni}\left(D_{50}=3 \mu \mathrm{m}\right)$, c) prah $\mathrm{Ni}\left(D_{50}=8.5 \mu \mathrm{m}\right)$

follows: the outer radius is $20 \mathrm{~mm}$, the length $40 \mathrm{~mm}$ and thickness $18 \mathrm{~mm}$. Thereafter, the samples were dried and removed from the plaster mold. The final step was sintering which was conducted on all specimens at $1400{ }^{\circ} \mathrm{C}$ in a reducing atmosphere $\left(\mathrm{N}_{2} / \mathrm{H}_{2}\right)$.

An X-ray Rigaku MiniFlex X-ray diffractometer II was used to study the structure of the composites. The data were recorded using the "step-scanning" method in the $2 \theta$ mode with $\mathrm{Cu}-K_{\alpha 1.54}$ radiation.

The $\mathrm{Al}_{2} \mathrm{O}_{3}-\mathrm{Ni}$ composites microstructures were characterized using a SEM HITACHI SU-70 scanning 
electron microscope. Quantitative analysis of the graded region microstructures from SEM images was carried out using the Micrometer computer image analysis program. ${ }^{33}$

The hardness of the microstructures from outer sample to inner sample were measured with a Vickers hardness tester. The hardness measurements were made under a load of $49.03 \mathrm{~N}$.

\section{RESULTS AND DISCUSSION}

Figure 3 shows typical examples of fabricated tubes before and after sintering. Using the Archimedes method, it was found that the average sintering shrinkage was about $13 \%$. A tube having a post-sintering diameter of $17 \mathrm{~mm}$, inner radius $6.5 \mathrm{~mm}$ and $40 \mathrm{~mm}$ could be fabricated successfully (i.e. without breakage of the cast tubes during subsequent drying and sintering) with a relatively high consolidation ( $>98.8 \%$ of relative density). No damage in the form of cracks or voids on the surface of samples were noticed. The X-ray data from the surfaces and the cross-sections of composites confirmed the presence of the two phases $\mathrm{Ni}$ and $\mathrm{Al}_{2} \mathrm{O}_{3}$. Figure 4 presents an typical diffraction pattern.

In Figure 5 the graded distribution of metal particles in $\mathrm{Al}_{2} \mathrm{O}_{3}$-Ni composites is shown. The grey area is $\mathrm{Al}_{2} \mathrm{O}_{3}$ and the bright area is Ni. Three zones of Ni particles of the samples can be distinguished in the cross-section. A quantitative analysis of the photomicrographs using the Micrometer computer image analysis program ${ }^{33,34}$ yielded the compositional profile variations shown in Figure 6. The measurements show that in area $A$, the nickel particle content was equal to $12 \%$ of volume fractions per $1 \mathrm{~mm}$ width in both samples. Between areas A and B there is a mild increase in nickel particles. In area B there was a maximum of nickel particles in both composites. In the case of the nickel powder with the larger particle size $\left(D_{50}=8.5 \mu \mathrm{m}\right)$ it was observed that zone $\mathrm{B}$ is narrower than zone $\mathrm{A}$. In area B there was a

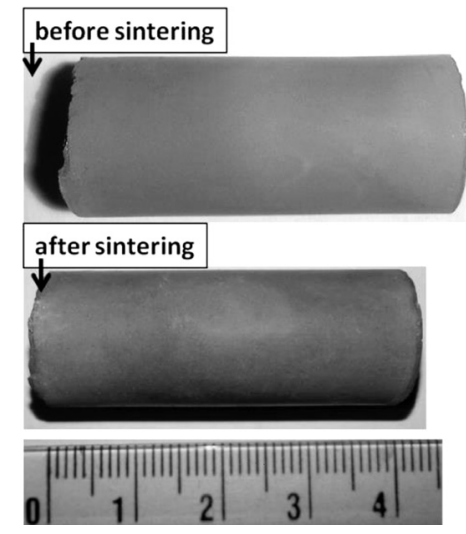

Figure 3: Views of composite sample prepared using a Ni powder $\left(D_{50}=8.5 \mu \mathrm{m}\right)$ before and after sintering

Slika 3: Izgled kompozitnega vzorca, pripravljenega z uporabo prahu Ni $\left(D_{50}=8,5 \mu \mathrm{m}\right)$, pred in po sintranju

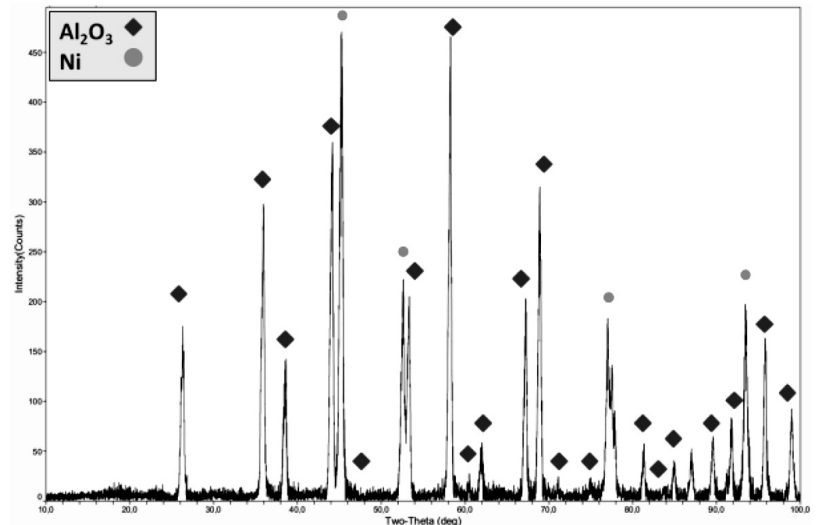

Figure 4: Diffraction patterns of the sample prepared using a $\mathrm{Ni}$ powder $\left(D_{50}=8.5 \mu \mathrm{m}\right)$

Slika 4: Rentgenogram vzorca, izdelanega z uporabo prahu Ni $\left(D_{50}=\right.$ $8,5 \mu \mathrm{m})$

maximum of nickel particles equal to about $28 \%$ of volume fractions per $560 \mu \mathrm{m}$ wide for the sample prepared using Ni $D_{50}=8.5 \mu \mathrm{m}$ powder. In contrast, the sample prepared using a Ni powder $\left(D_{50}=3 \mu \mathrm{m}\right)$ was contained $25 \%$ of volume fractions per $840 \mu \mathrm{m}$. Then there was a sharp decline in nickel particles. However, in area $\mathrm{C}$ there was a mild decrease, down to $0 \%$ of volume fractions, in the percentage of nickel particles.

The motion of metal particles in a slurry under centrifugal force can be determined by Stokes' law. ${ }^{35}$ According to this law the velocity of the particles is proportional to the square of the particles' diameter. Therefore the migration distance is greater in the case of larger particles. For this reason the width of zone B is smaller in the case of samples prepared with $8.5 \mu \mathrm{m} \mathrm{Ni}$ than for composites with $3 \mu \mathrm{m} \mathrm{Ni}$ powder.

The hardness values measured from the outer to the inner periphery are shown in Figure 7. It has been found that the hardness profiles for both series $(3 \mu \mathrm{m}$ and 8.5 $\mu \mathrm{m} \mathrm{Ni}$ powders) have similar behaviour (Figure 8). In region A hardness values in the range 1000-1300 HV are found for both series. Region A results from the removal

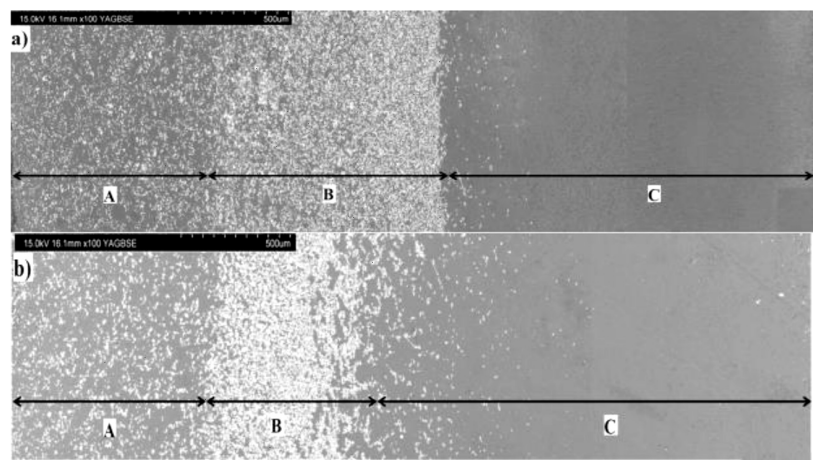

Figure 5: SEM photo of cross-section of composite: a) the sample prepared using a Ni powder $\left(D_{50}=3 \mu \mathrm{m}\right)$ and b) the sample prepared using a Ni powder $\left(D_{50}=8.5 \mu \mathrm{m}\right)$

Slika 5: SEM-posnetek preseka kompozita: a) vzorec, pripravljen z uporabo prahu Ni $\left(D_{50}=3 \mu \mathrm{m}\right)$ in b) vzorca, pripravljenega $\mathrm{z}$ uporabo prahu Ni $\left(D_{50}=8,5 \mu \mathrm{m}\right)$ 


\section{J. ZYGMUNTOWICZ et al.: METAL PARTICLES SIZE INFLUENCE ON GRADED STRUCTURE IN COMPOSITE Al $2 \mathrm{O}_{3}-\mathrm{Ni}$}

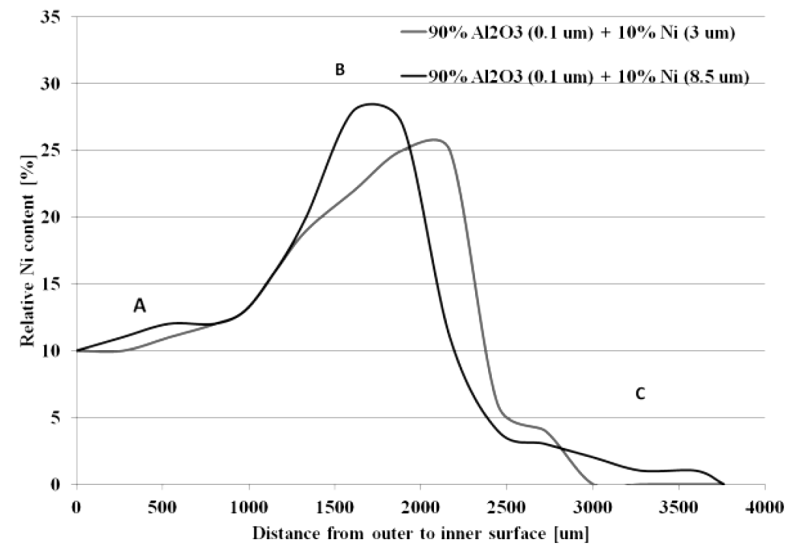

Figure 6: Changes in $\mathrm{Al}_{2} \mathrm{O}_{3}-\mathrm{Ni}$ composites metallic phase content from outer zone to inner

Slika 6: Spreminjanje vsebnosti kovinske faze v kompozitu $\mathrm{Al}_{2} \mathrm{O}_{3}-\mathrm{Ni}$ od zunanjega področja $\mathrm{v}$ notranjost

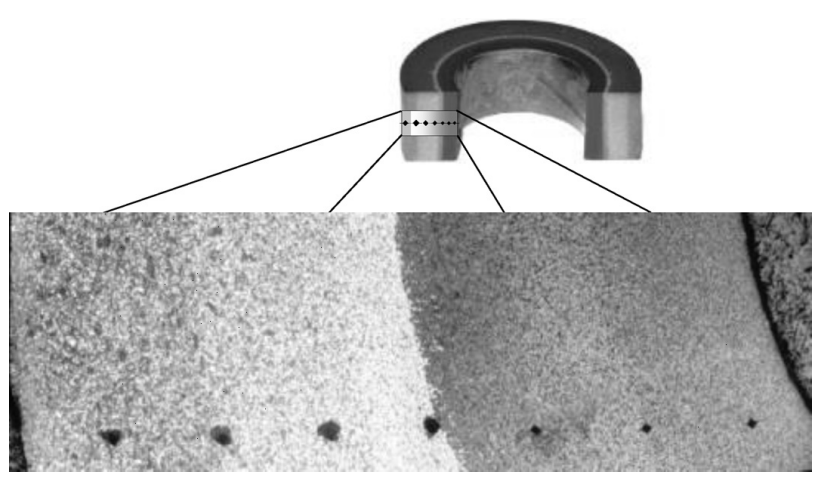

Figure 7: Scheme of hardness testing

Slika 7: Prikaz meritve trdote

of fluid through capillary action in the plaster mold. In Figure 7 a slightly lower hardness is observed in the area between $\mathrm{A}$ and $\mathrm{B}$ due to the increase of nickel particles in the composite. The maximum amount of nickel particles in the region $\mathrm{B}$ corresponds to the lowest hardness values. This part of the sample was produced as a result of centrifugal acceleration. As expected, in both series of samples the maximum hardness values are observed in region $\mathrm{C}$, at the inner edge of the casting due to the absence of nickel particles. The area $\mathrm{C}$ in both samples corresponds to hardness values in the range 1800-1920 HV.

\section{CONCLUSIONS}

$\mathrm{Al}_{2} \mathrm{O}_{3}$-Ni FGM ceramic matrix composites with a graded distribution of Ni particles have been successfully produced by the centrifugal slip casting method.

Quantitative analysis of the graded microstructure in the composites revealed that the graded zones depend on the size of the starting metal particles in the slurry.

By changing the content of the metallic phase it is possible to control the hardness profile. As a result of the

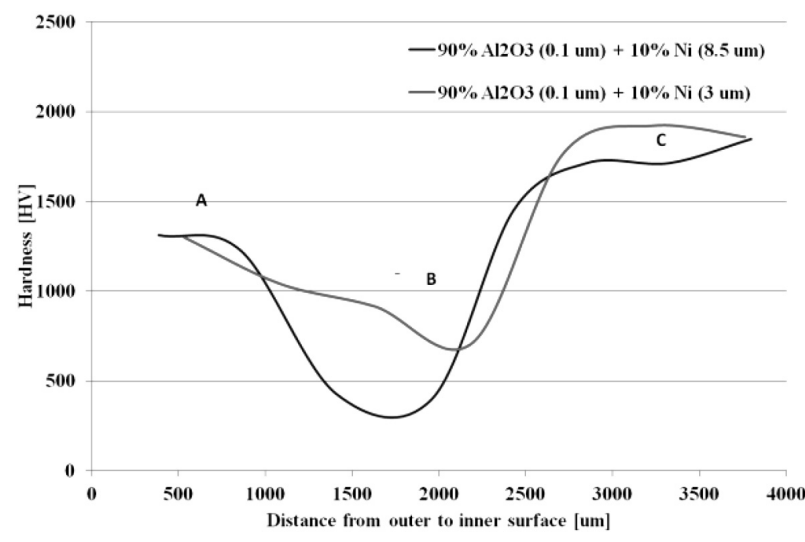

Figure 8: Variation in hardness from the outer edge of $\mathrm{Al}_{2} \mathrm{O}_{3}-\mathrm{Ni}$ functionally graded composites

Slika 8: Spreminjanje trdote od zunanjega roba funkcionalno stopenjskega kompozita $\mathrm{Al}_{2} \mathrm{O}_{3}-\mathrm{Ni}$

centrifugal slip casting method used, the packing of the powder particles prevents grain growth.

\section{Acknowledgments}

The authors would like to thank Professor M. Szafran and his Team from the Faculty of Chemistry of Warsaw University of Technology for help in preparing the samples. The results presented in this paper were obtained as part of the the Polish National Science Centre (NCN) project No. 2013/11/B/ST8/0029.

\section{REFERENCES}

${ }^{1}$ T. Ogawa, Y. Watanabe, H. Sato, I. S. Kim, Y. Fukui, Theoretical study on fabrication of functionally graded material with density gradient by a centrifugal solid-particle method, Composites: Part A, 37 (2006), 2194-2200, doi:10.1016/j.compositesa.2005.10.002

${ }^{2}$ Y. Fukui, Fundamental Investigation of Functionally Gradient Material Manufacturing System using Centrifugal Force, JSME international Journal, 34 (1991), 144-148, doi:10.1299/jsmec1988.34.144

${ }^{3}$ A. Neubrand, J. Neubrand, Gradient materials: an overview of a novel concept, Zeitschrift für Metallkunde, 88 (1997), 358-371

${ }^{4}$ D. Delfosse, B. Ilschner, Pulvermetallurgische Herstellung von Gradientenwerkstoffen, Matt.-wiss., 23 (1992), 235-240, doi:10.1002/ mawe. 19920230705

${ }^{5}$ J. G. Yeo, S. C. Choi, Zirconia-stainless steel functionally graded material by tape casting, Journal of the European Ceramic Society, 18 (1998), 1281-1285, doi:10.1016/S0955-2219(98)00054-5

${ }^{6}$ Y. P. Zeng, D. L. Jiang, T. Watanabe, Fabrication and properties of tape-casting laminated and functionally gradient alumina-titanium carbide materials, Journal of American Ceramic Society, 83 (2000), 2999-3003, doi:10.1111/j.1151-2916.2000.tb01673.x

${ }^{7}$ A. L. Dumont, J. P. Bonnet, T. Chartier, J. Ferreira, $\mathrm{MoSi}_{2} / \mathrm{Al}_{2} \mathrm{O}_{3}$ FGM: elaboration by tape casting and SHS, Journal of the European Ceramic Society, 21 (2001), 2353-2360, doi:10.1016/S0955-2219 (01)00198-4

${ }^{8}$ S. S. Tjong, Z. Ma, Microstructural and mechanical characteristics of in situ metal matrix composite, Materials Science and Engineering, 29 (2000) 3-4, 49-114, doi:10.1016/S0927-796X(00)00024-3

${ }^{9}$ A. Tomsia, E. Saiz, H. Ishibashi, M. Diaz, J. Requena, J. Moya, Powder processing of Mullite/Mo functionally graded materials, Journal of the European Ceramic Society, 18 (1998), 1365-1371, doi:10.1016/S0955-2219(98)00066-1 


\section{J. ZYGMUNTOWICZ et al.: METAL PARTICLES SIZE INFLUENCE ON GRADED STRUCTURE IN COMPOSITE $\mathrm{Al}_{2} \mathrm{O}_{3}-\mathrm{Ni}$}

${ }^{10}$ A. Mortensen, S. Suresh, Functionally graded metals and metal-ceramic composites: Part I. Processing, International Materials Reviews, 40 (1995), 239-265, doi:10.1179/imr.1995.40.6.239

${ }^{11}$ B. Marple, J. Boulanger, Graded casting of materials with continuous gradients, Journal of American Ceramic Society, 77 (1994) 10, 2747-2750, doi:10.1111/j.1151-2916.1994.tb04670.x

${ }^{12}$ A. J. Sanchez-Herencia, K. Morinaga, J. S. Moya, $\mathrm{Al}_{2} \mathrm{O}_{3} / \mathrm{Y}-\mathrm{TZP}$ Continuous Functionally Graded Ceramics by Filtration-Sedimentation, Journal of the European Ceramic Society, 17 (1997), 1551-1554, doi:10.1016/S0955-2219(97)00003-4

${ }^{13}$ J. Chu, H. Ishibashi, K. Hayashi, H. Takebe, K. Moringa, Slip casting of continuous functionally graded material, Journal of the Ceramic Society of Japan, 101 (1993), 818-820

${ }^{14}$ A. Lawley, R. Doherty, ASM handbook A, powder metal technologies and applications, unit: Spray forming, 1998, 408-419

${ }^{15}$ P. Grant, I. Palmer, I. Stone, Spray formed aerospace alloys, Materials World, 7 (1999) 6, 331-333

${ }^{16} \mathrm{~S}$. Oike, Y. Watanabe, Development of in-situ $\mathrm{Al}-\mathrm{Al}_{2} \mathrm{Cu}$ functionally graded materials by a centrifugal method, International Journal of Materials and Product Technology, 16 (2001), 40-49, doi:10.1504/ IJMPT.2001.005394

${ }^{17}$ S. Nai, M. Gupta, C. Lim, Synthesis and wear characterization of Al based, free standing functionally graded materials: effect of different matrix compositions, Composites Science and Technology, 63 (2003), 1895-1909, doi:10.1016/S0266-3538(03)00158-1

${ }^{18}$ K. Yamagiwa, Y. Watanabe, Y. Fukui, P. Kapranos, Novel recycling system of aluminum and iron wastes in-situ $\mathrm{Al}-\mathrm{Al}_{3} \mathrm{Fe}$ functionally graded material manufactured by a centrifugal method, Materials Transactions, 44 (2003) 12, 2461-2467

${ }^{19}$ Y. Watanabe, R. Sato, K. Matsuda, Evaluation of particle size and particle shape distributions in $\mathrm{Al}-\mathrm{Al}_{3} \mathrm{Ni}$ FGMs fabricated by a centrifugal in-situ method, Science and Engineering of Composite Materials, 11 (2004), 2-3

${ }^{20}$ J. Vleugels, G. Anné, S. Put, O. van der Biest, Thick plate-shaped $\mathrm{Al}_{2} \mathrm{O}_{3} / \mathrm{ZrO}_{2}$ composites with continuous gradient processed by electrophoretic deposition, Materials Science Forum, 423 (2003) 4, 171-176, doi:10.4028/www.scientific.net/MSF.423-425.171

${ }^{21}$ P. Sarkar, S. Datta, P. Nicholson, Functionally graded ceramic/cera$\mathrm{mic}$ and metal/ceramic composites by electrophoretic deposition, Composites Part B, 28 (1997) 1-2, 49-56

${ }^{22}$ Y. Chen, T. Li, J. Ma, A functional gradient ceramic monomorph actuator fabricated using electrophoretic deposition, Ceramics International, 30 (2004) 5, 683-687, doi:10.1016/j.ceramint.2003. 08.008

${ }^{23}$ A. Boccaccini, I. Zhitomirsky, Application of electrophoretic and electrolytic deposition techniques in ceramic processing, Current Opinion in Solid State and Material Science, 6 (2002), 251-260
${ }^{24}$ S. Put, G. Anné, J. Vleugels, Functionally graded hard metals with a continuously graded symmetrical profile, Materials Science Forum, 423 (2003) 4, 33-38, doi:10.4028/www.scientific.net/MSF.423425.33

${ }^{25}$ S. Put, G. Anné, J. Vleugels, Gradient profile prediction in functionally graded materials processed by electrophoretic deposition, Acta Materialia, 51 (2003) 20, 6303-6317, doi:10.1016/S1359-6454(03) 00463-4

${ }^{26}$ A. Ruys, J. Kerdic, C. Sorrel, Thixotropic casting of ceramic-metal functionally gradient materials, Journal of Materials Science, 31 (1996) 16, 4347-4355, doi:10.1007/BF00356459

${ }^{27}$ J. Lackner, W. Waldhauser, R. Ebner, B. Major, T. Schöberl, Structural, mechanical and tribological investigations of pulsed laser deposited titanium nitride coatings, Thin Solid Films, 453-454 (2004), 195-202, doi:10.1016/j.tsf. 2003.11.106

${ }^{28}$ P. Willmott, J. Huber, Pulse laser vaporization and deposition, Reviews of Modern Physics, 72 (2000), 315-328, doi:10.1103/ RevModPhys.72.315

${ }^{29}$ L. S. Sigl, P. A. Mataga, B. J. Dalgleish, R. M. Mc Meeking, A. G. Evans, On the toughness of brittle materials reinforce with a ductile phase, Acta Metall., 36 (1998) 4, 945-953, doi:10.1016/00016160(88)90149-6

${ }^{30}$ O. Sbaizero, G. Pezzoti, Influence of the metal particle size on toughness of $\mathrm{Al}_{2} \mathrm{O}_{3} / \mathrm{Mo}$ composite, Acta Mater., 48 (2000), 985-992, doi:10.1016/S1359-6454(99)00349-3

${ }^{31}$ X. Su, J. Yeomans, Microstructure and fracture toughness of nickel particle toughened alumina Science, 31 (1996), 875-880, doi:10.1007/BF00352885

${ }^{32}$ M. Szafran, K. Konopka, E. Bobryk, K. J. Kurzydłowski, Ceramic matrix composites with gradient concentration of metal particles, Journal of the European Ceramic Society, 27 (2007), 651-654, doi:10.1016/j.jeurceramsoc.2006.04.046

${ }^{33}$ J. Michalski, T. Wejrzanowski, R. Pielaszek, K. Konopka, W. Łojkowski, K. J. Kurzydłowski, Application of image analysis for characterization of powders, Materials Science Poland, 23 (2005) 1, 79-86

${ }^{34}$ J. Zygmuntowicz, A. Miazga, K. Konopka, W. Kaszuwara, M. Szafran, Forming graded microstructure of $\mathrm{Al}_{2} \mathrm{O}_{3}-\mathrm{Ni}$ composite by centrifugal slip casting, Composites Theory and Practice, 15 (2015) $1,44-47$

${ }^{35}$ Y. Watanabe, K. Kawamoto, K. Matsuda, Particle Size Distributions of Functionally Graded Materials Fabricated by Centrifugal SolidParticle Method, Composite Science and Technology, 62 (2002), 881-888, doi:10.1016/S0266-3538(02)00023-4 